\title{
Pain, click and crepitation as factors associated with temporomandibular dysfunction in Parkinson's disease
}

\author{
Dor, estalido e crepitação como fatores associados à disfunção temporomandibular na doença \\ de Parkinson
}

Taysa Vannoska de Almeida Silva ${ }^{1}$, Amanda do Vale Sobral ${ }^{2}$, Renato Mariano da Silva², Vilma Lucia dos Santos Almeida², Maria das Graças Wanderley de Sales Coriolano ${ }^{3}$, Carla Cabral dos Santos Accioly Lins ${ }^{3}$

\section{ABSTRACT}

BACKGROUND AND OBJECTIVES: Parkinson's disease leads to mandibular movements that affect the masticatory cycle and induce orofacial pain, one of the main clinical alterations found in temporomandibular dysfunction. Thus, the present study aimed to analyze the possible factors associated with temporomandibular dysfunction and to verify the frequency of the dysfunction in this population.

METHODS: This was a cross-sectional study in which the participants were evaluated using the Diagnostic Criteria for Temporomandibular Dysfunction research, used to classify the temporomandibular dysfunction and to obtain by physical examination and self-report the variables studied.

RESULTS: A total of 139 people with Parkinson's disease were evaluated. Of these, 77 met the eligibility criteria, with $70 \%$ of the sample being male, with an average age of $62 \pm 9$ years; Parkinson's disease diagnosis time of $6 \pm 4$ years and with $71 \%$ of the sample in the moderate stage of Parkinson's disease. No significant associations were found between age, gender, time and stage of the disease with temporomandibular dysfunction. Of the variables analyzed, the significant results showed that the presence of pain $(\mathrm{OR}=10.92,95 \% \mathrm{CI}=2.25-59.93, \mathrm{p}<0.001)$ has a greater chance of developing temporomandibular dysfunction, crepitation (Kappa $=0.34, \mathrm{p}<0.004)$ reflects moderate accuracy in the classification of temporomandibular joint disorder and the click (negative predictive value $=77 \%, \mathrm{p}<0.032$ ) increases the probability of having temporomandibular dysfunction.

1. Universidade Federal de Pernambuco, Programa de Pós-Graduaçăo em Gerontologia, Recife, PE, Brasil.

2. Universidade Federal de Pernambuco, Curso de Graduação em Odontologia, Recife, PE, Brasil.

3. Universidade Federal de Pernambuco, Programa de Pós-Graduação em Gerontologia, Departamento de Anatomia, Recife, PE, Brasil.

Submitted in December 14, 2017.

Accepted for publication on July 16, 2018.

Conflict of interests: none - Sponsoring sources: none.

Correspondence to:

Av. Prof. Moraes Rego, 1235 - Cidade Universitária

50670-901 Recife, PE, Brasil.

E-mail: taysavnk.fisio@gmail.com

(c) Sociedade Brasileira para o Estudo da Dor
CONCLUSION: Therefore, in this study, the frequency of the temporomandibular dysfunction was 30\%, and it was observed that the factors associated with the dysfunction in people with Parkinson's disease were: pain, click, and crackle.

Keywords: Facial pain, Noise, Parkinson's disease, Referred pain, Temporomandibular joint disorders.

\section{RESUMO}

JUSTIFICATIVA E OBJETIVOS: A doença de Parkinson leva a movimentos mandibulares que afetam o ciclo mastigatório e induzem a dor orofacial, uma das principais alteraçôes clínicas encontradas na disfunçáo temporomandibular. Sendo assim, o presente estudo objetivou analisar os possíveis fatores associados à disfunção temporomandibular e verificar a frequência da disfunção nessa população.

MÉTODOS: Trata-se de um estudo de corte transversal, no qual os participantes foram avaliados com o Critério de Diagnóstico para pesquisa em disfunçấo temporomandibular, utilizado para classificar a disfunção temporomandibular e obter, através do exame físico e autorrelato, as variáveis estudadas.

RESULTADOS: Foram avaliadas 139 pessoas com doença de Parkinson. Dessas, 77 encontraram-se dentro dos critérios de elegibilidade, sendo que $70 \%$ da amostra era do sexo masculino, com média de idade de $62 \pm 9$ anos, tempo de diagnóstico da doença de Parkinson de $6 \pm 4$ anos e com $71 \%$ da amostra no estágio moderado. Não foram encontradas associações significativas entre a idade, sexo, tempo e estágio da doença com a disfunção temporomandibular. Das variáveis analisadas, os resultados significativos mostraram que a presença de dor $(\mathrm{OR}=10,92$; IC95\%=2,25-59,93; $\mathrm{p}<0,001)$ representa uma maior chance de desenvolver a disfunçáo temporomandibular, a crepitação (Kappa $=0,34 ; \mathrm{p}<0,004)$ reflete uma precisão moderada na classificação do transtorno da articulação temporomandibular e o estalido (valor preditivo negativo $=77 \%$; $\mathrm{p}<0,032)$ aumenta a probabilidade de ter a disfunção temporomandibular.

CONCLUSÁO: Neste estudo, a frequência de disfunção temporomandibular foi de $30 \%$ e verificou-se que os fatores associados à disfunção em pessoas com doença de Parkinson foram dor, estalido e crepitação.

Descritores: Doença de Parkinson, Dor facial, Dor referida, Ruídos, Transtornos da articulação temporomandibular. 


\section{INTRODUCTION}

Population aging brought a new epidemiological profile, with the increase in chronic and degenerative diseases. Among them is the Parkinson's disease (PD), which is a clinical syndrome of the central nervous system (CNS), typically associated with the loss of dopaminergic neurons of the compact part of the substancia nigra of the midbrain. Such loss results in the following motor symptoms: tremor, bradykinesia, muscle rigidity and postural instability ${ }^{1}$.

It is considered the second most common disease among individuals over 60 years of age, with 36 thousand new cases per year emerging in Brazil ${ }^{2,3}$. It affects both genders, but more often in men and it is present in all countries, ethnic groups and socio-economic classes ${ }^{4,5}$.

PD is classified per stages, according to the Hoehn and Yahr scale $^{6}$, indicating the general state of the patient and classifying into mild stage (I), with unilateral manifestations (tremor, rigidity, and bradykinesia) and ability to live independently. Moderate stage (II and III), in which the signs of the disease are bilateral, coupled with possible speech abnormalities, bent posture, and abnormal gait, added to balance disorders. However, patients are still able to live independently. Stages IV and V correspond to more the severe forms of the disease, in which patients need a lot of help or are bedridden/in wheelchairs ${ }^{7}$.

These symptoms can lead to several orofacial manifestations, such as the absence of facial expression, with a characteristic "mask" face; reduced blink rate; tremors on the forehead, eyelids, lips and tongue muscles. PD produces mandibular movements that impact the masticatory cycle; an important action on the fragmentation of food into smaller particles, preparing them for swallowing and digestion. The disease also induces orofacial pain $^{8}$, which is one of the main clinical changes found in temporomandibular dysfunction (TMD).

TMD is defined as a set of joint and muscle disorders caused by injuries in the morphology or functionality of the temporomandibular system, with a multifactorial and dynamic etiology 9 . Its main clinical changes are headaches, neck pain, pain in the temporomandibular joint (TMJ), mouth opening limitation, muscle fatigue, mouth opening deviation and joint noises ${ }^{10}$.

Being a multifactorial disease characterized by a set of signs and symptoms, there are different instruments for its assessment, organized as questionnaires ${ }^{11}$, anamnestic ${ }^{12}$ and clinical indexes ${ }^{13}$, and diagnostic criteria ${ }^{14}$. Each of these instruments has advantages, disadvantages, and limitations, as well as distinct applicability for clinical and research use.

Based on these considerations, the objective of this study was to analyze the possible factors associated with TMD in PD and check the frequency of TMD in this population in order to establish therapeutic strategies.

\section{METHODS}

This is a cross-sectional study, conducted from November 2016 to July 2017, in people with PD recruited at the Neurology Outpatient Clinic of the Hospital das Clínicas (HC), in partnership with the Pro-Parkinson Extension Program of the Federal University of Pernambuco (UFPE).

To set the sample size, calculations were based on the concepts and formulas available in the literature, using the parameters of 95\% confidence interval; 5\% accuracy; 5\% alpha and 20\% beta. The expected proportion of TMD in PD was $20.33 \%{ }^{15}$. The considered population size was 300 people registered in the Neurology Outpatient Clinic of the HC. As a result, it was determined a sample of 137 people.

The inclusion criteria were: 1) clinical diagnosis of idiopathic PD in stages from 1 to 3 of the Hoehn and Yahr scale; 2) both genders; 3) taking antiparkinsonian drugs (phase "on"); 4) patients with teeth or wearing dentures; 5) oriented patients and under family member care.

The exclusion criteria were: 1) patients with other neurological diseases associated with PD; 2) unsatisfactory cognitive level; 3) edentulous in both dental arches, and 4) who underwent any type of jaw surgery or surgery for PD.

The studied variables were pain, night clenching/grinding, day clenching/grinding, uncomfortable/unusual bite, morning stiffness and tinnitus and were obtained by questions. Click and crepitation were assessed by the physical examination found in the Research Diagnostic Criteria for Temporomandibular Disorders (RDC/TMD), translated and validated for use in Brazil ${ }^{14}$.

Initially, PD patients from the Neurology Outpatient Clinic of the HC/UFPE were contacted and received the information about the research. Those who agreed to participate were screened according to the eligibility criteria. And then they were assessed by the RDC/TMD ${ }^{14}$.

The assessment started with the cognitive screening performed with the Mini-Mental State Examination (MMSE). The cutoff points depended on the patient's education level: illiterate/ low schooling -18 points, and 8 years or more of schooling - 26 points ${ }^{16}$. Regarding the classification of PD signs and symptoms, the original version of the Hoehn and Yahr scale was used ${ }^{6}$. This scale allows the classification of each individual in 5 stages of severity: stage 1 indicates mild disability; stages 2 and 3 indicate moderate disability and stages 4 and 5 indicate severe disability. Patients were in phase "on," that is, taking routine drugs, levodopa and/or dopaminergic agonists, according to medical prescription.

TMD signs and symptoms were assessed using the Brazilian version of the RDC/TMD, which is the gold standard for this type of assessment. It has two axes, allowing the measurement of physical findings on the axis I and the assessment of the psychosocial status on axis II, including the self-perception of oral health ${ }^{17}$. Axis I consist of an intraoral and extraoral clinical examination, involving the analysis of mandibular movements and joint sounds, as well as the palpation of the masticatory muscles tender points. Axis II consists of a psychosocial questionnaire with 31 items. The diagnosis was determined with the help of a data-based correction key for both axes ${ }^{18}$.

The diagnoses obtained were divided into three groups: group I-muscle diagnoses (myofascial pain with limited opening); group II - disk displacements (disc displacement with reduction, disc displacement without reduction with limited opening, 
and disk displacement without reduction and without limited opening); and group III- arthralgia, arthritis, arthrosis (arthralgia, osteoarthritis and osteoarthritis of TMJ). Therefore, a single individual can have multiple diagnoses ${ }^{18}$.

However, as a rule for the diagnosis, at most one muscular diagnosis (group I); and at most one diagnosis from group II and one from group III for each side could be attributed to one individual. The diagnoses within any group are mutually exclusive. This means that, in principle, an individual may receive one diagnosis from zero (no diagnosable conditions) up to five diagnoses (a muscle diagnosis, one from Group II and one from group III, for each side $)^{18}$.

\section{Training of the examiners}

The assessments were conducted by a team of dental surgeon, physiotherapist and undergraduate and postgraduate students, who were trained and leveled. Due to the clinical characteristics of the sample, the questionnaires were answered in an interview format. The questions were always read in the same order, presenting the answer options for each question. Each potential participant received a brief explanation about the research objectives, and those eligible answered the questionnaire.

The study was approved by the Human Research Ethics Committee of the Federal University of Pernambuco-UFPE (CAAE: 59421416.9.0000.5208). All participants signed the Free and Informed Consent Form (FICT).

\section{Statistical analysis}

Descriptive statistics and frequency counts were used to characterize the sample. First, the sample was stratified according to the diagnosis of TMD to study the association according to the demographic variables (age, gender, time of disease and evolution of PD). Second, the association between each possible pair of variables was evaluated. An odds ratio (OR) Chi-square (X2) with a $95 \%$ confidence interval (CI) was applied to the analysis, using the Statistica 13.2 software with a significance level of 0.05 .

Regarding the TMD diagnosis, the sensitivity analyses, specificity analysis, positive predictive value (PPV), negative predictive value (NPV) and the level of agreement by the Kappa coefficient were used to evaluate the accuracy of the variables click, crepitation, and pain.

Sensitivity was considered as the capacity of the clinical characteristics (pain, click, and crepitation) in identifying correctly those with TMD; and specificity was considered as the capacity of the variables, when absent, to move away from the TMD. Unlike sensitivity and specificity, the PPV and the NPV depend on the prevalence of the dysfunction in the sample. The PPV indicates the proportion of people with TMD among those who had a positive test for the variables; the NPV is the proportion of healthy subjects (with no TMD) among the negative ones for the predictor variables. Therefore, the higher the prevalence of the disease in the population tested, the greater the PPV and the smaller the NPV. The lower the prevalence of the disease in the population tested, the smaller the PPV and greater the NPV ${ }^{19}$. To assess the level of correlation among the studied variables and the TMD diagnosis, the Kappa coefficient was applied, character- ized as a measure of association used to describe and test the level of agreement (reliability and precision) on the classification of the dysfunction. The different levels of agreement are: <zero: there is no agreement; zero - 0.20: minimum agreement; $0.21-0.40$ : reasonable agreement; $0.41-0.60$ : moderate agreement; $0.61-0.80$ : substantial agreement; $0.81-1.0$ : perfect agreement ${ }^{20}$.

\section{RESULTS}

A total of 139 people were invited from the HC Neurology sector. After the exclusion of those who did not meet the eligibility criteria, the final sample consisted of 77 individuals (Figure 1). Of the 77 evaluated participants, $60 \%$ were male with an average age of $62 \pm 9$ years. The average time elapsed since the PD diagnosis was $6 \pm 4$ years, and according to the Hoehn and Yahr scale, $71 \%$ were in the moderate stage of PD (Table 1).

The TMD frequency in the sample was $30 \%$, corresponding to 23 individuals who presented predisposing signs and symptoms



Figure 1. Sample selection flowchart

Table 1. Characteristics of the sample

\begin{tabular}{lcc}
\hline Variables & $\mathrm{n}$ & Average \pm standard deviation \\
\hline Age (years) & & $62 \pm 9$ \\
Time of PD diagnosis (years) & & $6 \pm 4$ \\
Gender (male/female) & $(46 / 31)$ & \\
Schooling (years) & & $10 \pm 411$ \\
Income (MW) & & \\
$1 / 2$ to 1 & 7 & \\
1 to 2 & 35 & \\
2 to 3 & 12 & \\
3 to 5 & 13 & \\
5 to 10 & 6 & \\
15 to 20 & 1 & \\
DI & 3 & \\
Hoehn and Yahr & 22 & \\
Mild (1) & 55 & \\
Moderate (2 and 3) & & \\
\hline PD= Parkinson's disease; MW = minimum wage; DI = did not inform.
\end{tabular}


to the onset of the dysfunction, separated into the RDC/TMD groups (Figure 2).

The distribution of the association between TMD and the variables was by age, gender, time of disease and evolution of the PD and are shown in table 2. Despite the increased frequency of the disorder in females, at the age below 60 years, and time of the disease less than 10 years and in the moder- ate stage of PD, there were no significant differences for the studied variables.

The associations among the variables studied and the TMD are expressed in table 3 . There was a significant association with the variables pain $(\mathrm{p}=0.001, \mathrm{OR}=10.92$, CI95\%=2.25-59.93), click $(p=0.032, O R=3.21, C I 95 \%=1.00-10.4)$ and crepitation $(\mathrm{p}=0.004, \mathrm{OR}=5.3, \mathrm{CI} 95 \%=1.53-18.7)$.

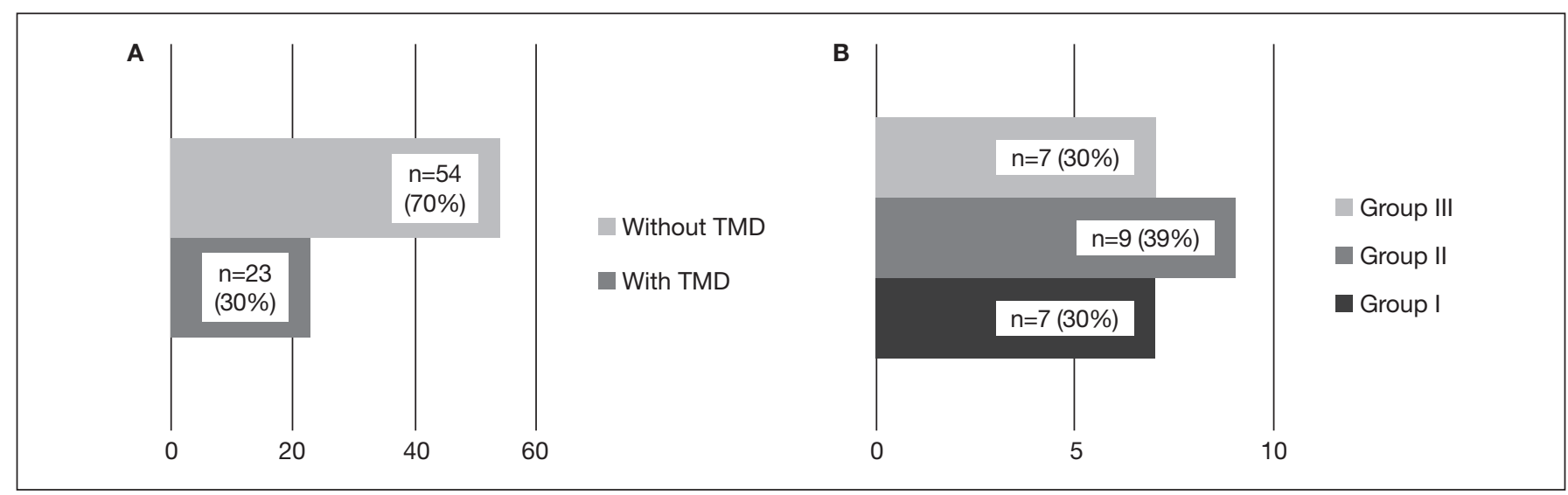

Figure 2. A) The frequency of people in the groups with and without temporomandibular dysfunction; B) Distribution in the groups according to the characteristics of the Research Diagnostic Criteria for Temporomandibular Disorders

Group I = pain = Group II = click; Group III = crepitation .

Table 2. Association between temporomandibular joint dysfunction and the variables age, gender, time of the disease and stage of Parkinson's disease

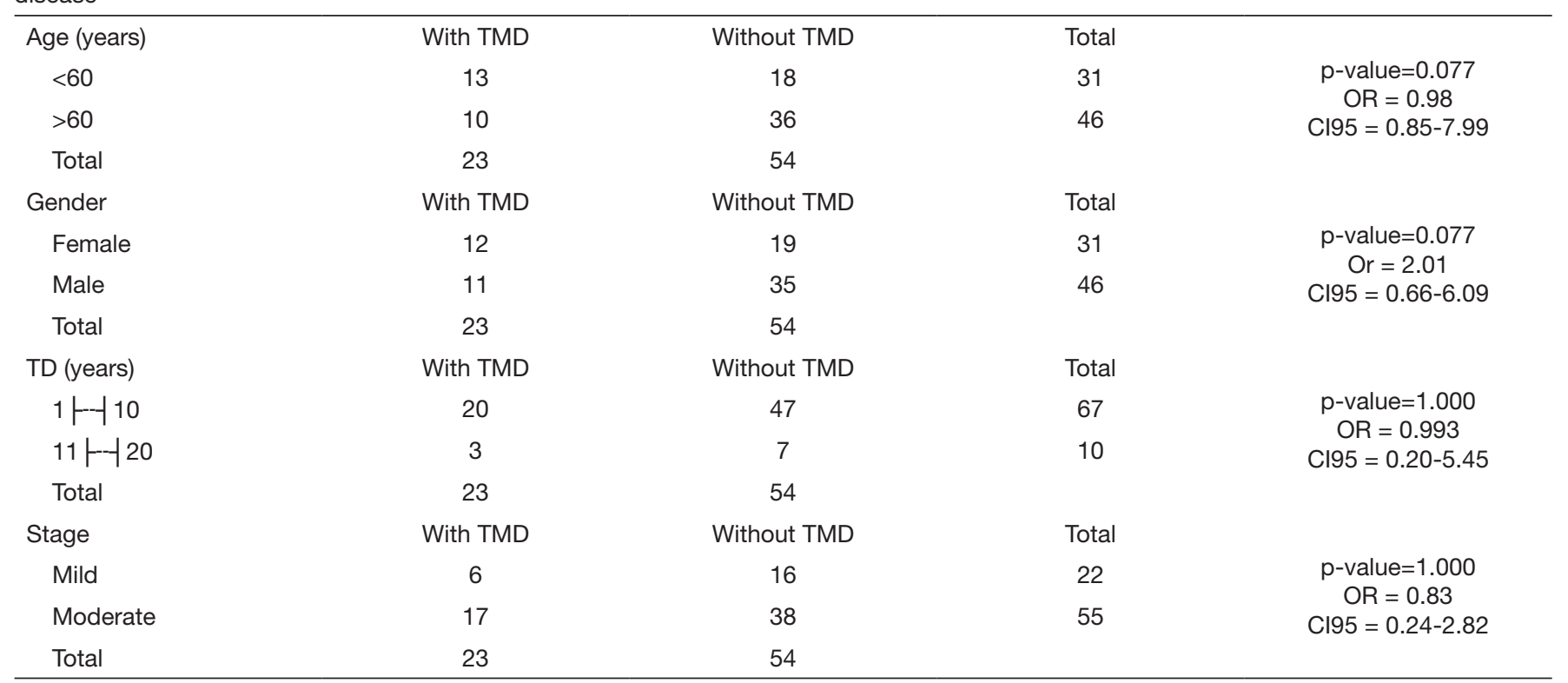

$\mathrm{TD}=$ time of the disease; $\mathrm{TMD}=$ temporomandibular dysfunction; $\mathrm{OR}=$ odds ratio; $\mathrm{Cl}$ = confidence interval.

Tabela 3. Associação entre disfunção temporomandibular com as variáveis estudadas

\begin{tabular}{|c|c|c|c|c|}
\hline Pain & With pain & Without pain & Total & $p$-value $=0.001^{*}$ \\
\hline With TMD & 9 & 14 & 23 & $\begin{array}{c}\mathrm{OR}=10.92 \\
\mathrm{Cl} 95=2.25-59.93\end{array}$ \\
\hline Without TMD & 3 & 51 & 54 & Kappa $=0.33$ \\
\hline Total & 12 & 65 & & $\begin{array}{l}\text { Sens. }=0.39 \\
\text { Spe. }=0.90 \\
\text { PPV }=75 \% \\
\text { NPV }=78 \%\end{array}$ \\
\hline
\end{tabular}


Table 3. Association between temporomandibular joint dysfunction and the variables studied - continuation



$\overline{\mathrm{TMD}}$ = temporomandibular dysfunction; $\mathrm{NC}=$ night clenching; $\mathrm{DC}=$ daytime clenching; $\mathrm{UC}=$ unusual chewing; $\mathrm{MS}=$ morning stiffness; OR = odds ratio; $\mathrm{Cl}=$ confidence interval; Sens. = sensitivity; Spe. = specificity; PPV = positive predictive value; NPV = negative predictive value; ${ }^{*} \mathrm{p}<0.05$.

\section{DISCUSSION}

TMD encompasses a variety of muscle and joint signs and symptoms, characterized by pain and/or functional change (dysfunction) of the stomatognathic system ${ }^{9}$. Among the studies about TMD frequency, there is no consensus among authors as to its presence in the elderly. Some indicate a frequency of similar symptoms in many age groups ${ }^{21}$, others point to the low prevalence in the elderly, with a higher incidence between 20 to 45 years of age $e^{22-24}$, while others have observed a high prevalence of TMD in older people ${ }^{23,25}$. In this study, no significant data were found regarding the association between age and the presence of TMD. However, it was observed a higher frequency in non-elderly people, with an average age of 52 years, corroborating the research by Guarda-Nardini et al..$^{26}$ who observed a peak of the TMD frequency at ages around 52 years.
The frequency of TMD in people with PD in the present sample was $30 \%$, and even with no significant association found between having the dysfunction and the gender, the highest frequency was found in women. This result corroborates a recent study that evaluated the presence of the dysfunction in 42 people with PD and found a $23.08 \%$ higher frequency in women ${ }^{27}$. This is because women have a generalized tissue laxity, increased estrogen levels, making the joints more flexible and loose $\mathrm{e}^{28}$.

Bakke et al. ${ }^{29}$ observed that the orofacial functions of individuals with PD can be impaired due to the severity of the motor symptoms that can also influence the occurrence of TMD in this population. This corroborates the results of this research that found an increase in the frequency of TMD, according to the stage of the disease, although no significant association has been found. The time of diagnosis of the disease showed no association with 
the presence of the dysfunction in the studied population. However, no studies were found in the literature that held a similar association among these variables for discussion.

The average in years of schooling shows that the subjects of the study had basic education and monthly income of 1 to 2 minimum wages. Such characteristic fits the sample in the group of people who have a higher probability of being diagnosed with TMD since when investigating the correlation between the sociodemographic data and the presence of the dysfunction in non-institutionalized aged people, the researchers had found a significant correlation for gender, schooling, and income $\mathrm{e}^{30,31}$.

The variables pain, click, crepitation, night clenching/grinding, daytime clenching/grinding, uncomfortable/unusual bite, morning stiffness and ringing in the ears were assessed for sensitivity, which indicates the ability of the diagnostic test to identify patients correctly. As for specificity, which is characterized by the capacity to identify healthy subjects, it is a useful test to confirm a diagnosis that is suggested by less specific tests ${ }^{1}$.

The values obtained for sensitivity were lower for the variables studied in comparison with the specificity (pain $=94 \%$, click $=78 \%$, and crepitation $=85 \%$ ), being able to inform that those who do not present these variables in the diagnostic test will not be classified in the TMD groups. Due to the low TMD frequency in the sample, the NPV (pain=78\%, click=77\% and crepitation $=79 \%$ ) showed higher rates for the variables studied in relation to the PPV, expressing a higher probability of a person with a negative test for pain, click and crepitation not having TMD. However, although it is described in the literature that night clenching/grinding, daytime clenching/grinding, uncomfortable/unusual bite, morning stiffness and ringing in the ears are factors associated with TMD ${ }^{32-35}$, this correlation was not observed in this study.

The pain was assessed by self-report on question 3 of axis II of the RDC/TMD questionnaire: "Did you had pain in the face, in regions as the cheeks (maxilla), the sides of the head, the front of the ear or the ear, in last the 4 weeks"? A significant association with TMD was observed $(\mathrm{OR}=10.92$, CI95\% $=2.25-59.93)$. Therefore, those who have pain have 10.92 times greater chance of having the dysfunction. This variable obtained a reasonable agreement (Kap$\mathrm{pa}=0.38$ ) to classify the sample with the dysfunction.

Dantas et al. ${ }^{36}$ when evaluating people in the 41-60 years age group attending the Orofacial Pain Control Service, observed that the major TMJ complaint was the pain (44\%). In addition, Torres, Campos and Fillipini ${ }^{10}$ also evaluated the primary clinical change found in TMD and observed that it is the pain in the TMJ region and the muscle pain, followed by fatigue, limitation of mouth opening, opening deviation and joint noises. These data do not corroborate the findings of this study that when classifying the sample with TMD in the RDC/TMD groups, the pain was not the major complaint (30\%-group I).

The click and crepitation were assessed by the physical examination found on axis I, during the opening and closing at maximum usual intercuspation, in which a joint noise (click or crepitation) is reproducible in two of three movements performed by the jaw ${ }^{37}$. A significant association between presenting a click in the TMJ with the presence of TMD was observed $(\mathrm{OR}=3,21$, IC95\% $=1,00$ -
10,37). Thus, people who have clicks have 3.21 times greater chance of having TMD in comparison with those who do not have this sign. This variable showed poor accuracy (Kappa $=0.25$ ) in the classification of the dysfunction, not corroborating the studies $^{38,39}$ that, when assessing TMJ sounds with the joint morphology, confirmed that clicks and crepitation may be correlated with the signs of an abnormal morphology of the joints.

Moreover, Group-II of the RDC/TMD (disk displacement), characterized by the presence of the click, showed a higher percentage $(39 \%)$ in the sample, corroborating studies that when evaluating the prevalence of TMD signs and symptoms in adults ${ }^{40}$ and in older people ${ }^{25}$, observed that the perception of noises in the TMJ represented 71.5 and $38 \%$, respectively. However, such studies do not inform what noises were observed. Furthermore, no studies were found that assess this theme in people with PD.

Crepitation had a significant association with TMD (OR=5.3, CI95\% $=1.53-18.7$ ). Therefore, people who have crepitation have 5.3 times greater chance of having the TMD. This variable presented a reasonable reliability $(\mathrm{Kappa}=0.34)$ in the classification of the dysfunction, corroborating the study by Guarda-Nardini et al. ${ }^{26}$ who evaluated the age-related differences in the diagnosis of temporomandibular disorder and observed that, with age increased, the most present TMD symptom is crepitation, with an average value of $27.03 \%$ for ages between 38 and 56 years, and $23 \%$ for over 56 years. This finding is also in accordance with the $30 \%$ percentage found in this research for the Group III of the RDC: arthralgia, arthritis, and osteoarthritis, which is characterized by the presence of crepitation.

This study has the typical limitations of a cross-sectional study, which only allows the creation of an association, and does not allow conclusions about causality, and the fact of not achieving the calculated sample n. Thus, further work should be conducted with the total $\mathrm{n}$ to obtain significant results with other variables, as well as longitudinal studies should be performed to determine the cause and effect relationships between PD and TMD.

\section{CONCLUSION}

It was found that the TMD frequency in the sample was 30\% and that the associated factors were: pain, clicks, and crepitation. These data help in the search for better therapeutic strategies for the studied population.

\section{ACKNOWLEDGMENTS}

We thank Dr. John Asano, neurologist, for giving access to the Neurology Outpatient Clinic of the Hospital das Clínicas, which made the data collection possible, and Dra. Nadja Asano for the technical support during the activities in the Outpatient Clinic.

\section{REFERENCES}

1. Tysnes OB, Storstein A. Epidemiology of Parkinson's disease. J Neural Transm. 2017;124(8):901-5.

2. Gerlach O, Winogrodzka A, Weber WE. Clinical problems in the hospitalized Parkinson's disease patient: systematic review. Mov Disord. 2011;26(2):197-208. 
3. Souza C, Almeida H, Sousa J, Costa P, Silveira Y, Bezerra J. A doença de Parkinson e o processo de envelhecimento motor: uma revisão de literatura. Rev Neurociências. 2011;19(4):718-23

4. Wirdefeldt K, Adami HO, Cole P, Trichopoulos D, Mandel J. Epidemiology and etiology of Parkinson's disease: a review of the evidence. Eur J Epidemiol. 2011;26(Suppl 1):S1-58.

5. Kalia LV, Lang AE. Parkinson's disease. Lancet. 2015;386(9996):896-912.

6. Hoehn MM, Yahr MD. Parkinsonism: onset, progression and mortality. Neurology. 1967;17(5):427-42

7. Mello MP, Botelho AC. Correlaçấo das escalas de avaliaçấo utilizadas na doença de Parkinson com aplicabilidade na fisioterapia. Fisioter Mov. 2010;23(1):121-7.

8. Ribeiro GR, Campos CH, Rodrigues Garcia RC. Parkinson's disease impairs masticatory function. Clin Oral Investig. 2017;21(4):1149-56.

9. Dym H, Israel H. Diagnosis and treatment of temporomandibular disorders. Dent Clin North Am. 2012;56(1):149-61.

10. Torres F, Campos L, Fillipini H. Efeitos dos tratamentos fisioterapêuticos e odontológicos em pacientes com disfunção temporomandibular. Fisioter Mov. 2012;25(1):117-25.

11. Manfredi AP, Silva AA, Vendite LL. Avaliação da sensibilidade do questionário de triagem para dor orofacial e desordens temporomandibulares recomendado pela Academia Americana de Dor Orofacial. Rev Bras Otorrinolaringol. 2001;67(6):763-8.

12. Fonseca DM, Bonfante G, Valle AL, Freitas SF. Diagnóstico pela anamnese da disfunçâo craniomandibular. RGO. 1994;42(1):23-8.

13. Pehling J, Schiffman E, Look J, Shaefer J, Lenton P, Fricton J. Interexaminer reliability and clinical validity of the temporomandibular index: a new outcome measure for temporomandibular disorders. J Orofac Pain. 2002;16(4):296-304.

14. Dworkin S, LeResche L. Research diagnostic criteria for temporomandibular disorders: review, criteria, examinations and specifications, critique. Craniomandib Disord. 1992;6(4):301-55.

15. Silva PF, Biasotto-Gonzalez DA, Motta LJ, Silva SM, Ferrari RA, Fernandes KP, et al. Impact in oral health and the prevalence of temporomandibular disorder in individuals with Parkinson's disease. J Phys Ther Sci. 2015;27(3):887-91.

16. Folstein MF, Folstein SE, McHugh PR. "Mini-mental state". A practical method for grading the cognitive state of patients for the clinician. J Psychiatr Res. 1975;12(3):189-98.

17. de Lucena LB, Kosminsky M, da Costa LJ, de Góes PS. Validation of the Portuguese version of the RDC/TMD Axis II questionnaire. Braz Oral Res. 2006;20(4):312-7.

18. Chaves TC, Oliveira AS, Grossi DB. Principais instrumentos para avaliação da disfunção temporomandibular, parte I: índices e questionários; uma contribuição para a prática clínica e de pesquisa. Fisioter Pesqui. 2008;15(1):92-100.

19. Sousa MR, Ribeiro AL. Revisão sistemática e meta-análise de estudos de diagnóstico e prognóstico: um tutorial. Arq Bras Cardiol. 2009;92(3):241-51.

20. Perroca MG, Gaidzinski RR. [Assessing the inter-rater reliability of an instrument for the classification of patients--Kappa's quotient]. Rev Esc Enferm USP. 2003;37(1):7280. Portuguese.

21. Rammelsberg P, LeResche L, Dworkin S, Mancl L. Longitudinal outcome of temporomandibular disorders: a 5-year epidemiological study of muscle disorders defined by research diagnostic criteria for temporomandibular disorders. J Orofac Pain. 2003;17(1):9-20.

22. Ozan F, Polat S, Kara I, Küçük D, Polat HB. Prevalence study of signs and symptoms of temporomandibular disorders in a Turkish population. J Contemp Dent Pract. 2007;8(4):35-42.
23. Camacho JG, Oltramari-Navarro PV, Navarro Rde L, Conti AC, Conti MR, Marchiori LL, et al. Signs and symptoms of temporomandibular disorders in the elderly. Codas. 2014;26(1):76-80.

24. Magnusson T, Egermarki I, Carlsson G. A prospective investigation over two decades on signs and symptoms of temporomandibular disorders and associated variables. A final summary. Acta Odontol Scand. 2005;63(2):99-109.

25. Almeida L, Farias A, Soares M, Cruz J, Cruz R, Lima M. Disfunção temporomandibular em idosos. RFO. 2008;13(1):35-8.

26. Guarda-Nardini L, Piccotti F, Mogno G, Favero L, Manfredini D. Age-related differences in temporomandibular disorder diagnoses. Cranio. 2012;30(2):103-9.

27. Silva PF, Motta LJ, Silva SM, Ferrari RA, Fernandes KP, Bussadori SK. Computerized analysis of the distribution of occlusal contacts in individuals with Parkinson's disease and temporomandibular disorder. Cranio. 2015;15;2151090315Y0000000012. [Epub ahead of print].

28. Andrade T, Frare J. Estudo comparativo entre os efeitos de técnicas de terapia manual isoladas e associada a laserterapia de baixa potência sobre a dor em pacientes com disfunçăo temporomandibular. RGO. 2008;56(3):287-95.

29. Bakke M, Larsen SL, Lautrup C, Karlsborg M. Orofacial function and oral health in patients with Parkinson's disease. Eur J Oral Sci. 2011;119(1):27-32.

30. Cavalcanti MO, Lima CM, Lima JM, Gomes I, Goldim JR. Prevalência da disfunção temporomandibular em idosos năo institucionalizados. Estud Interdiscipl Envelhec. 2015;20(2):551-66.

31. Sampaio NM, Oliveira MC, Ortega AO, Santos LB, Alves TD. Temporomandibular disorders in elderly individuals: the influence of institutionalization and sociodemographic factors. Codas. 2017;29(2):e20160114.

32. Silva TV, Coriolano MG, Lins CC. Temporomandibular joint dysfunction in Parkinson's disease: an integrative literature review. Rev CEFAC. 2017;19(5):702-11.

33. Fernandes G, Franco-Micheloni AL, Siqueira JT, Gonçalves DA, Camparis CM. Parafunctional habits are associated cumulatively to painful temporomandibular disorders in adolescents. Braz Oral Res. 2016;30. pii: S1806-83242016000100214.

34. Fernandes G, Siqueira JT, Godoi Gonçalves DA, Camparis CM. Association between painful temporomandibular disorders, sleep bruxism and tinnitus. Braz Oral Res. 2014;28. pii: S1806-83242014000100220.

35. Takashima M, Arai Y, Kawamura A, Hayashi T, Takagi R. Quantitative evaluation of masseter muscle stiffness in patients with temporomandibular disorders using shear wave elastography. J Prosthodont Res. 2017;61(4):432-8.

36. Dantas AM, Santos EJ, Vilela RM, Lucena LB. Perfil epidemiológico de pacientes atendidos em um Serviço de Controle da Dor Orofacial. Rev Odontol da UNESP. 2015;6;44(6):313-9.

37. Pereira Júnior FJ, Favilla EE, Dworkin ES, Huggins S. Critérios de diagnóstico para pesquisa das disfunçóes temporomandibulares (RDC/TMD). Traduçâo oficial para a língua portuguesa. JBC J Bras Clin Odontol Iintegr. 2004;8(47):384-95.

38. Bertoli FM, Bruzamolin CD, Pizzatto E, Losso EM, Brancher JA, de Souza JF. Prevalence of diagnosed temporomandibular disorders: a cross-sectional study in Brazilian adolescents. PLoS One. 2018;13(2):e0192254.

39. Hirata FH, Guimarāes AS, Oliveira JX, Moreira CR, Ferreira ET, Cavalcanti MG Evaluation of TMJ articular eminence morphology and disc patterns in patients with disc displacement in MRI. Braz Oral Res. 2007;21(3):265-71.

40. Silva W, Silva F, Ribeiro C, Silva L, Oliveira M. Prevalência de sinais e sintomas de disfunçốes temporomandibulares (DTM) em adultos tratados no CETASE: estudo piloto transversal. Rev Port Estomatol Med Dent Cir Maxilofac. 2011;2(4):200-4. 